\title{
Disinfection By-Products Regulation: Zero ng/L Target
}

\author{
Djamel Ghernaout ${ }^{1,2 *}$, Noureddine Elboughdiri ${ }^{1,3}$ \\ ${ }^{1}$ Chemical Engineering Department, College of Engineering, University of Ha'il, Ha'il, KSA \\ ${ }^{2}$ Chemical Engineering Department, Faculty of Engineering, University of Blida, Blida, Algeria \\ ${ }^{3}$ Département de Génie Chimique de Procédés, Laboratoire Modélisation, Analyse, et Commande des systèmes, Ecole Nationale \\ d'Ingénieurs de Gabès (ENIG), Rue Omar Ibn-Elkhattab, Gabès, Tunisia \\ Email: ^djamel_andalus@hotmail.com
}

How to cite this paper: Ghernaout, D. and Elboughdiri, N. (2020) Disinfection By-Products Regulation: Zero ng/L Target. Open Access Library Journal, 7: e6382. https://doi.org/10.4236/oalib.1106382

Received: April 30, 2020

Accepted: May 16, 2020

Published: May 19, 2020

Copyright $\odot 2020$ by author(s) and Open Access Library Inc.

This work is licensed under the Creative Commons Attribution International License (CC BY 4.0).

http://creativecommons.org/licenses/by/4.0/

\section{(c) (i) Open Access}

\begin{abstract}
Ten years ago, I was asked by a health agency about my opinion concerning the guidelines for drinking water quality. I suggested fixing the maximum acceptable concentration (MAC) to zero ng/L, once and for all for each pollutant. Such a proposition is founded on the fact that regularly the MAC is lowered following some considerations like 1) the lethal dose determination and toxicity studies, 2) the progress recorded in analytical methods and water treatment technologies and, 3) the technical-economic features of the country. Attaining the zero ng/L target is related to applying the best available technologies such as those used in the International Space Station. This work focuses on the hard challenges in dealing with the disinfection by-products (DBPs). This work concludes that, in terms of poisoning, unregulated products $v s$. regulated products, the question does not matter. DBPs formation should be absolutely avoided. Moreover, if DBPs are unwantedly produced, all of them must be securely removed from the water at the highest level as other organic matters. Finally, disinfection is killing microorganisms present in water; but, it is also killing human beings drinking water via its inherent toxic DBPs. Treating chemically water should be avoided.
\end{abstract}

\section{Subject Areas}

Chemical Engineering \& Technology, Public Health

\section{Keywords}

COVID-19 Pandemic, Coronavirus, Hospital Wastewater, Disinfection, Chlorination, Disinfection By-Products (DBPs) 


\section{Introduction}

Disinfecting water is considered as a main public health conquering since it considerably decreased waterborne illness and augmented life expectancy [1]. Nevertheless, a not planned sequel was the formation of disinfection by-products (DBPs), which are generated via the reaction of disinfectants (chlorine, chloramine, ozone, chlorine dioxide, ultraviolet (UV)) with natural and anthropogenic organic matter, bromide, and iodide [2] [3] [4]. Such compounds are produced for any specific objective but are generated throughout water treatment [5] [6] [7]. Until now, more than 700 DBPs have been defined, and of those, around only 100 have been strictly examined for their existence, generation, and quantitative analytical biological toxicity [8] [9] [10].

In the early 1970s, at most a few of DBPs were investigated, foremost trihalomethanes (THMs) [11] [12]. Later, such THMs were observed to be prevalent in chlorinated water and were as well discovered to be carcinogenic in laboratory animals [1] [13]. Consequently, the earliest DBP regulations were announced [14] [15] [16]. The emerging U.S. Environmental Protection Agency (EPA), which was instituted in 1970, started to regulate THMs (chloroform, bromoform, bromodichloromethane, and chlorodibromomethane) below the 1979 Safe Drinking Water Act [1]. Subsequently, more toxicity facts were acquired for five haloacetic acids, bromate, and chlorite; and these were attached to the regulation below the Stage 1 and Stage 2 [17] [18] [19]. The World Health Organization, European Union, and many different nations also have guidelines or regulations for some DBPs in drinking water [1].

This work focuses on the hard challenges in dealing with the disinfection by-products (DBPs). Fundamental interrogations relating DBPs monitoring are presented. The fact that regulating DBPs is important or not is also discussed.

\section{Deep and Basic Questions}

Richardson and Plewa [1], well-known experts in the DBPs field, posted a relevant question: "Are we controlling the right DBPs?" Previous researches on human epidemiology support the plan of regulating and controlling DBPs since numerous investigations noted a hazard of bladder cancer, colorectal cancer, miscarriage, and birth defects [1] [20] [21].

One more matter in question is that water is not as it was consumed seventy years earlier [1] [22] [23]. It is ever-changing [24] [25] [26]. During the time that regulations and ecological protection actions greatly enhanced the protection of water, potable water is unlike what it was a half-century ago [14] [27] [28].

If in the end all the different DBPs were as well decreased with the regulated DBPs, the situation would be better [1]. In fact, the more poisonous iodo-DBPs and nitrogen-containing DBPs (N-DBPs) [29] could be produced at much greater degrees when plants change to chloramine [30]. A change to ozone could as well lead to an augmented generation of bromate, as well as unregulated halonitromethane, haloaldehyde, haloketone, and haloacid DBPs, with secondary 
chlorination [15] [31] [32]. Paradoxically, UV could response with natural organic matter (NOM) to augment the production of considerably hazardous halonitromethanes if secondary chlorine is implemented [33] [34] [35]. Since ozone and UV do not provide a residual disinfectant, chlorine or chloramine is frequently injected as an additional disinfectant to keep disinfection in the distribution system [36] [37] [38].

Additional elements also influence water sources like population increases, climate change, water usage, and wastewater reuse [39] [40] [41]. As an example, climate change increases wastewater pollutants in water sources, as well as concentrates NOM, bromide, and iodide, constituting circumstances for worsening the hazardous effects on water [1] [42] [43] [44] [45].

\section{DBPs Toxicity: Regulating DBPs Significance}

Since the earliest DBP poisoning investigations launched five decades ago, more than 100 additional DBPs were rigorously analyzed for cytotoxicity, genotoxicity, endocrine disruption, and carcinogenicity [46] [47] [48]. Several unregulated DBPs were found more dangerous than regulated ones [1] [49] [50].

More technical details can be found in the excellent discussion performed by Richardson et al. [1] and references cited in.

Finally, treatment master plans must be adopted to avoid the formation of DBPs, whether regulated or unregulated [51] [52] [53]. Viable techniques involving the usage of granular activated carbon or membranes to retain DBP precursors (then injecting a smaller injection of chlorine for killing pathogens), utilizing UV pursued by a smaller dosage of chlorine [1] [14] [54] (Figure 1).

\section{Conclusions}

Considered as the latest technique, post-disinfection is extremely crucial for the classical potable water treatment [55] [56] [57]. Disinfection target is to kill microorganisms that cause diseases in water to make certain the potable water security [58] [59] [60]. But, the quality of the fountainhead water becomes worse and worse due to rising natural and artificial water contaminations [61] [62] [63]. DBPs are generated at what time disinfectants (chlorine, chlorine dioxide, chloramines or ozone) interact with NOM, anthropogenic contaminants, bromide, and iodide in the potable water treatment chain [64] [65] [66]. As well the regulated DBPs (such as THMs, HAAs, bromate and chlorite), several additional unregulated DBPs have been detected [67] [68] [69]. Nitrosoamines are the elements of these new DBPs, which are strongly carcinogenic, mutagenic, and teratogenic [70] [71] [72]. The main points drawn from this review may be drawn as:

1) The first objective of water treatment is to render water secure to consume by making certain that it is without of pathogens and poisonous compounds; the second target is to render it a desirable drink by eliminating unwanted turbidity, tastes, colors, and odors [73] [74] [75]. Considering the first objective render 


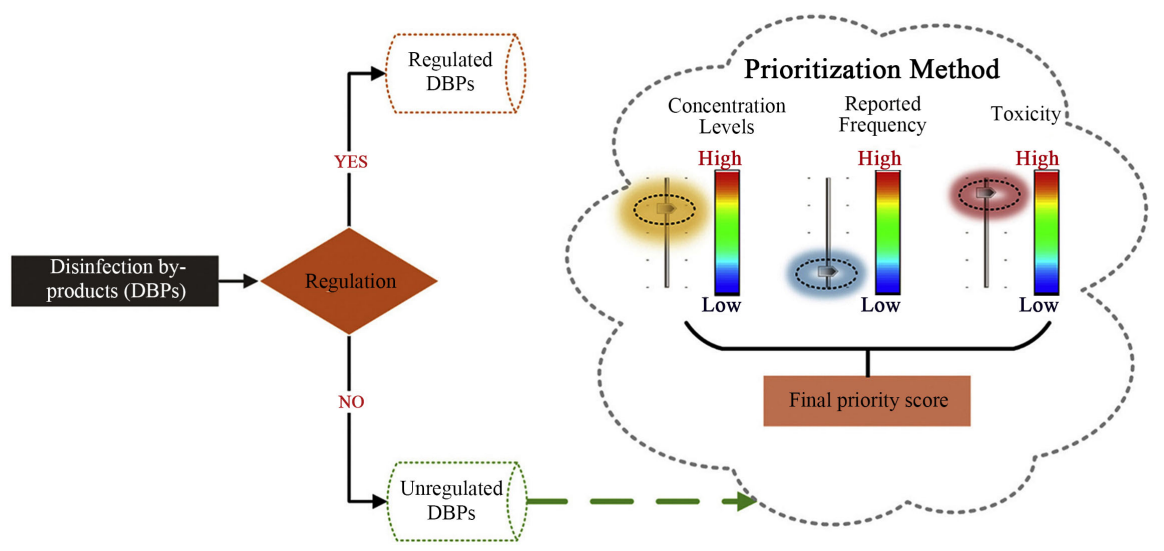

Figure 1. Regulated DBPs vs. unregulated DBPs [53].

water without pathogens and toxic matters, it is obvious that disinfecting by injecting chemicals is an impossible compromise since disinfection kills microorganisms but forms DBPs [76] [77]. Consequently, injecting chemical products into water must be avoided even if the mentioned reason is disinfecting water [14] [15].

2) Instead of chemical therapy, sure techniques such as physical processes like distillation and membrane processes should be urgently adopted to remove pathogens and organic compounds [14] [15].

3) Finally, at the COVID-19 period, this study arrives at its time since the Environmental Engineers and the Green Chemistry specialists have largely opened the discussion about polluting industry and preserving nature [78] [79] [80] [81].

\section{Acknowledgements}

This research has been funded by the Research Deanship of University of Ha'il, Saudi Arabia, through the Project RG-191190.

\section{Conflicts of Interest}

The authors declare no conflicts of interest regarding the publication of this paper.

\section{References}

[1] Richardson, S.D. and Plewa, M.J. (2020) To Regulate or Not to Regulate? What to Do with More Toxic Disinfection Byproducts? Journal of Environmental Chemical Engineering, 8, Article ID: 103939. https://doi.org/10.1016/j.jece.2020.103939

[2] Ghernaout, D., Naceur, M.W. and Aouabed, A. (2011) On the Dependence of Chlorine By-Products Generated Species Formation of the Electrode Material and Applied Charge during Electrochemical Water Treatment. Desalination, 270, 9-22. https://doi.org/10.1016/j.desal.2011.01.010

[3] Boucherit, A., Moulay, S., Ghernaout, D., Al-Ghonamy, A.I., Ghernaout, B., Naceur, M.W., Ait Messaoudene, N., Aichouni, M., Mahjoubi, A.A. and Elboughdiri, N.A. (2015) New Trends in Disinfection By-Products Formation upon Water Treatment. 
Journal of Research \& Developments in Chemistry, 2015, Article ID: 628833. https://doi.org/10.5171/2015.628833

[4] Ghernaout, D. and Elboughdiri, N. (2020) Strategies for Reducing Disinfection By-Products Formation during Electrocoagulation. Open Access Library Journal, 7, e6076. https://doi.org/10.4236/oalib.1106076

[5] Richardson, S.D., Plewa, M.J., Wagner, E.D., Schoeny, R. and DeMarini, D.M. (2007) Occurrence, Genotoxicity, and Carcinogenicity of Regulated and Emerging Disinfection By-Products in Drinking Water: A Review and Roadmap for Research. Mutation Research, 636, 178-242. https://doi.org/10.1016/j.mrrev.2007.09.001

[6] Richardson, S.D. and Ternes, T.A. (2011) Water Analysis: Emerging Contaminants and Current Issues. Analytical Chemistry, 83, 4614-4648.

https://doi.org/10.1021/ac200915r

[7] Ghernaout, D. and Elboughdiri, N. (2020) Disinfection By-Products: Presence and Elimination in Drinking Water. Open Access Library Journal, 7, e6140.

[8] Richardson, S.D. and Postigo, C. (2015) Formation of DBPs: State of the Science. In: Karanfil, T., Mitch, W.A., Westerhoff, P. and Xie, Y., Eds., Recent Advances in Disinfection By-Products, Am. Chem. Society, Washington DC, 189-214. https://doi.org/10.1021/bk-2015-1190.ch011

[9] Duirk, S.E., Lindell, C., Cornelison, C., Kormos, J.L., Ternes, T.A., Attene-Ramos, M.S., Osiol, J., Wagner, E.D., Plewa, M.J. and Richardson, S.D. (2011) Formation of Toxic Iodinated Disinfection By-Products from Compounds Used in Medical Imaging. Environmental Science \& Technology, 45, 6845-6854. https://doi.org/10.1021/es200983f

[10] Li, X.F. and Mitch, W.A. (2018) Drinking Water Disinfection Byproducts (DBPs) and Human Health Effects: Multidisciplinary Challenges and Opportunities. Environmental Science \& Technology, 52, 1681-1689. https://doi.org/10.1021/acs.est.7b05440

[11] Rook, J.J. (1974) Formation of Haloforms during Chlorination of Natural Waters. Water Treatment and Examination, 23, 234-243.

[12] Bellar, T.A., Lichtenberg, J.J. and Kroner, R.C. (1974) The Occurrence of Organohalides in Chlorinated Drinking Waters. Journal of the American Water Works Association, 66, 703-706. https://doi.org/10.1002/j.1551-8833.1974.tb02129.x

[13] Ghernaout, D. and Elboughdiri, N. (2020) Controlling Disinfection By-Products Formation in Rainwater: Technologies and Trends. Open Access Library Journal, 7, e6162. https://doi.org/10.4236/oalib.1106162

[14] Ghernaout, D. (2018) Disinfection and DBPs Removal in Drinking Water Treatment: A Perspective for a Green Technology. International Journal of Advances in Applied Sciences, 5, 108-117. https://doi.org/10.21833/ijaas.2018.02.018

[15] Ghernaout, D., Alghamdi, A., Aichouni, M. and Touahmia, M. (2018) The Lethal Water Tri-Therapy: Chlorine, Alum, and Polyelectrolyte. World Journal of Applied Chemistry, 3, 65-71. https://doi.org/10.11648/j.wjac.20180302.14

[16] Ghernaout, D. and Elboughdiri, N. (2020) Antibiotics Resistance in Water Mediums: Background, Facts, and Trends. Applied Engineering, 4, 1-6. https://doi.org/10.4236/oalib.1106003

[17] Ghernaout, D. (2017) Microorganisms' Electrochemical Disinfection Phenomena. EC Microbiology, 9, 160-169.

[18] Ghernaout, D., Touahmia, M. and Aichouni, M. (2019) Disinfecting Water: Electrocoagulation as an Efficient Process. Applied Engineering, 3, 1-12. 
[19] Ghernaout, D., Aichouni, M. and Touahmia, M. (2019) Mechanistic Insight into Disinfection by Electrocoagulation-A Review. Desalination and Water Treatment, 141, 68-81. https://doi.org/10.5004/dwt.2019.23457

[20] Ghernaout, D., Elboughdiri, N., Alghamdi, A. and Ghernaout, B. (2020) Trends in Decreasing Disinfection By-Products Formation during Electrochemical Technologies. Open Access Library Journal, 7, e6337. https://doi.org/10.4236/oalib.1106337

[21] Ghernaout, D. and Elboughdiri, N. (2020) Foresight Look on the Disinfection By-Products Formation. Open Access Library Journal, 7, e6349.

[22] Ghernaout, D. and Elboughdiri, N. (2019) Mechanistic Insight into Disinfection Using Ferrate (VI). Open Access Library Journal, 6, e5946.

[23] Ghernaout, D. and Elboughdiri, N. (2020) Eliminating Cyanobacteria and Controlling Algal Organic Matter-Short Notes. Open Access Library Journal, 7, e6252. https://doi.org/10.4236/oalib.1106252

[24] Ghernaout, D., Elboughdiri, N., Ghareba, S. and Salih, A. (2020) Coagulation Process for Removing Algae and Algal Organic Matter-An Overview. Open Access Library Journal, 7, e6272. https://doi.org/10.4236/oalib.1106272

[25] Ghernaout, D., Ghernaout, B. and Kellil, A. (2009) Natural Organic Matter Removal and Enhanced Coagulation as a Link between Coagulation and Electrocoagulation. Desalination and Water Treatment, 2, 203-222. https://doi.org/10.5004/dwt.2009.116

[26] Ghernaout, D., Naceur, M.W. and Ghernaout, B. (2011) A Review of Electrocoagulation as a Promising Coagulation Process for Improved Organic and Inorganic Matters Removal by Electrophoresis and Electroflotation. Desalination and Water Treatment, 28, 287-320. https://doi.org/10.5004/dwt.2011.1493

[27] Ghernaout, D., Ghernaout, B. and Naceur, M.W. (2011) Embodying the Chemical Water Treatment in the Green Chemistry-A Review. Desalination, 271, 1-10. https://doi.org/10.1016/j.desal.2011.01.032

[28] Ghernaout, D. (2017) Environmental Principles in the Holy Koran and the Sayings of the Prophet Muhammad. American Journal of Environmental Protection, 6, 75-79. https://doi.org/10.11648/j.ajep.20170603.13

[29] Plewa, M.J., Wagner, E.D., Muellner, M.G., Hsu, K.M. and Richardson, S.D. (2008) Comparative Mammalian Cell Toxicity of N-DBPs and C-DBPs. In: Karanfil, T., Krasner, S.W., Westerhoff, P. and Xie, Y., Eds., Occurrence, Formation, Health Effects and Control of Disinfection By-Products in Drinking Water, American Chemical Society, Washington DC, 36-50. https://doi.org/10.1021/bk-2008-0995.ch003

[30] Krasner, S.W., Weinberg, H.S., Richardson, S.D., Pastor, S.J., Chinn, R., Sclimenti, M.J., Onstad, G.D. and Thruston Jr., A.D. (2006) The Occurrence of a New Generation of Disinfection By-Products. Environmental Science \& Technology, 40, 7175-7185. https://doi.org/10.1021/es060353j

[31] Ghernaout, D. and Elboughdiri, N. (2020) Towards Enhancing Ozone Diffusion for Water Disinfection-Short Notes. Open Access Library Journal, 7, e6253.

[32] Ghernaout, D. and Elboughdiri, N. (2020) Is Not It Time to Stop Using Chlorine for Treating Water? Open Access Library Journal, 7, e6007.

[33] Reckhow, D.A., Linden, K.G., Kim, J., Shemer, H. and Makdissy, G. (2010) Effect of UV Treatment on DBP Formation. Journal of the American Water Works Association, 102, 100-113. https://doi.org/10.1002/j.1551-8833.2010.tb10134.x

[34] Ghernaout, D. and Elboughdiri, N. (2020) UV-C/ $\mathrm{H}_{2} \mathrm{O}_{2}$ and Sunlight $/ \mathrm{H}_{2} \mathrm{O}_{2}$ in the Core of the Best Available Technologies for Dealing with Present Dares in Domestic 
Wastewater Reuse. Open Access Library Journal, 7, e6161. https://doi.org/10.4236/oalib.1106161

[35] Ghernaout, D., Moulay, S., Ait Messaoudene, N., Aichouni, M., Naceur, M.W. and Boucherit, A. (2014) Coagulation and Chlorination of NOM and Algae in Water Treatment: A Review. International Journal of Environmental Monitoring and Analysis, 2, 23-34. https://doi.org/10.11648/j.ijema.s.2014020601.14

[36] Ghernaout, D. and Ghernaout, B. (2010) From Chemical Disinfection to Electrodisinfection: The Obligatory Itinerary? Desalination and Water Treatment, 16, 156-175. https://doi.org/10.5004/dwt.2010.1085

[37] Ghernaout, D. and Elboughdiri, N. (2019) Water Disinfection: Ferrate(VI) as the Greenest Chemical-A Review. Applied Engineering, 3, 171-180.

[38] Ghernaout, D. (2017) Water Treatment Chlorination: An Updated Mechanistic Insight Review. Chemistry Research Journal, 2, 125-138.

[39] Ghernaout, D. (2017) Water Reuse (WR): The Ultimate and Vital Solution for Water Supply Issues. International Journal of Sustainable Development Research, 3, 36-46. https://doi.org/10.11648/j.ijsdr.20170304.12

[40] Ghernaout, D., Alshammari, Y., Alghamdi, A., Aichouni, M., Touahmia, M. and Ait Messaoudene, N. (2018) Water Reuse: Extenuating Membrane Fouling in Membrane Processes. International Journal of Environmental Chemistry, 2, 1-12. https://doi.org/10.11648/j.ajche.20180602.12

[41] Ghernaout, D., Elboughdiri, N. and Al Arni, S. (2019) Water Reuse (WR): Dares, Restrictions, and Trends. Applied Engineering, 3, 159-170.

[42] Ghernaout, D., Elboughdiri, N. and Ghareba, S. (2019) Drinking Water Reuse: One-Step Closer to Overpassing the "Yuck Factor". Open Access Library Journal, 6, e5895. https://doi.org/10.4236/oalib.1105895

[43] Ghernaout, D., Elboughdiri, N. and Alghamdi, A. (2019) Direct Potable Reuse: The Singapore NEWater Project as a Role Model. Open Access Library Journal, 6, e5980. https://doi.org/10.4236/oalib.1105980

[44] Ghernaout, D. and Elboughdiri, N. (2019) Water Reuse: Emerging Contaminants Elimination-Progress and Trends. Open Access Library Journal, 6, e5981.

[45] Ghernaout, D. and Elboughdiri, N. (2020) On the Treatment Trains for Municipal Wastewater Reuse for Irrigation. Open Access Library Journal, 7, e6088.

[46] Wagner, E.D. and Plewa, M.J. (2017) CHO Cell Cytotoxicity and Genotoxicity Analyses of Disinfection By-Products: An Updated Review. Journal of Environmental Sciences, 58, 64-76. https://doi.org/10.1016/j.jes.2017.04.021

[47] Ghernaout, D. and Elboughdiri, N. (2020) Removing Antibiotic-Resistant Bacteria (ARB) Carrying Genes (ARGs): Challenges and Future Trends. Open Access Library Journal, 7, e6003. https://doi.org/10.4236/oalib.1106003

[48] Ghernaout, D. and Elboughdiri, N. (2020) Should We Forbid the Consumption of Antibiotics to Stop the Spread of Resistances in Nature? Open Access Library Journal, 7, e6138.

[49] Ghernaout, D. (2013) The Best Available Technology of Water/Wastewater Treatment and Seawater Desalination: Simulation of the Open Sky Seawater Distillation. Green and Sustainable Chemistry, 3, 68-88. https://doi.org/10.4236/gsc.2013.32012

[50] Ghernaout, D. (2014) The Hydrophilic/Hydrophobic Ratio vs. Dissolved Organics Removal by Coagulation-A Review. Journal of King Saud University-Science, 26, 169-180. https://doi.org/10.1016/j.jksus.2013.09.005

[51] Ghernaout, B., Ghernaout, D. and Saiba, A. (2010) Algae and Cyanotoxins Removal 
by Coagulation/Flocculation: A Review. Desalination and Water Treatment, 20, 133-143. https://doi.org/10.5004/dwt.2010.1202

[52] Ghernaout, D. and Naceur, M.W. (2011) Ferrate(VI): In Situ Generation and Water Treatment-A Review. Desalination and Water Treatment, 30, 319-332. https://doi.org/10.5004/dwt.2011.2217

[53] Mian, H.R., Hu, G., Hewage, K., Rodriguez, M.J. and Sadiq, R. (2018) Prioritization of Unregulated Disinfection By-Products in Drinking Water Distribution Systems for Human Health Risk Mitigation: A Critical Review. Water Research, 147, 112-131. https://doi.org/10.1016/j.watres.2018.09.054

[54] Ghernaout, D. and Ghernaout, B. (2012) On the Concept of the Future Drinking Water Treatment Plant: Algae Harvesting from the Algal Biomass for Biodiesel Production-A Review. Desalination and Water Treatment, 49, 1-18. https://doi.org/10.1080/19443994.2012.708191

[55] Ghernaout, D., Badis, A., Braikia, G., Matâam, N., Fekhar, M., Ghernaout, B. and Boucherit, A. (2017) Enhanced Coagulation for Algae Removal in a Typical Algeria Water Treatment Plant. Environmental Engineering and Management Journal, 16, 2303-2315. https://doi.org/10.30638/eemj.2017.238

[56] Ghernaout, D. (2018) Magnetic Field Generation in the Water Treatment Perspectives: An Overview. International Journal of Advances in Applied Sciences, 5, 193-203. https://doi.org/10.21833/ijaas.2018.01.025

[57] Ghernaout, D., Aichouni, M. and Alghamdi, A. (2018) Applying Big Data (BD) in Water Treatment Industry: A New Era of Advance. International Journal of Advances in Applied Sciences, 5, 89-97. https://doi.org/10.21833/ijaas.2018.03.013

[58] Ghernaout, D., Alshammari, Y. and Alghamdi, A. (2018) Improving Energetically Operational Procedures in Wastewater Treatment Plants. International Journal of Advances in Applied Sciences, 5, 64-72. https://doi.org/10.21833/ijaas.2018.09.010

[59] Al Arni, S., Amous, J. and Ghernaout, D. (2019) On the Perspective of Applying of a New Method for Wastewater Treatment Technology: Modification of the Third Traditional Stage with Two Units, One by Cultivating Microalgae and Another by Solar Vaporization. International Journal of Environmental Sciences \& Natural Resources, 16, Article ID: 555934. https://doi.org/10.19080/IJESNR.2019.16.555934

[60] Alshammari, Y., Ghernaout, D., Aichouni, M. and Touahmia, M. (2018) Improving Operational Procedures in Riyadh's (Saudi Arabia) Water Treatment Plants Using Quality Tools. Applied Engineering, 2, 60-71.

[61] Ghernaout, D. (2019) Reviviscence of Biological Wastewater Treatment-A Review. Applied Engineering, 3, 46-55.

[62] Ghernaout, D. (2019) Greening Cold Fusion as an Energy Source for Water Treatment Distillation-A Perspective. American Journal of Quantum Chemistry and Molecular Spectroscopy, 3, 1-5.

[63] Ghernaout, D. and Elboughdiri, N. (2019) Upgrading Wastewater Treatment Plant to Obtain Drinking Water. Open Access Library Journal, 6, e5959. https://doi.org/10.4236/oalib.1105959

[64] Ghernaout, D. and Elboughdiri, N. (2020) Electrochemical Technology for Wastewater Treatment: Dares and Trends. Open Access Library Journal, 7, e6020.

[65] Ghernaout, D., Elboughdiri, N. and Ghareba, S. (2020) Fenton Technology for Wastewater Treatment: Dares and Trends. Open Access Library Journal, 7, e6045. https://doi.org/10.4236/oalib.1106045

[66] Ghernaout, D. and Elboughdiri, N. (2020) Advanced Oxidation Processes for Wastewater Treatment: Facts and Future Trends. Open Access Library Journal, 7, 
e6139.

[67] Ghernaout, D. and Elboughdiri, N. (2020) Domestic Wastewater Treatment: Difficulties and Reasons, and Prospective Solutions-China as an Example. Open Access Library Journal, 7, e6141.

[68] Ghernaout, D., Alghamdi, A. and Ghernaout, B. (2019) Microorganisms' Killing: Chemical Disinfection vs. Electrodisinfection. Applied Engineering, 3, 13-19.

[69] Ghernaout, D. (2019) Electrocoagulation and Electrooxidation for Disinfecting Water: New Breakthroughs and Implied Mechanisms. Applied Engineering, 3, 125-133.

[70] Ghernaout, D. and Elboughdiri, N. (2019) Electrocoagulation Process Intensification for Disinfecting Water-A Review. Applied Engineering, 3, 140-147.

[71] Ghernaout, D. and Elboughdiri, N. (2019) Iron Electrocoagulation Process for Disinfecting Water-A Review. Applied Engineering, 3, 154-158.

[72] Ghernaout, D. (2019) Disinfection via Electrocoagulation Process: Implied Mechanisms and Future Tendencies. EC Microbiology, 15, 79-90.

[73] Ghernaout, D. and Elboughdiri, N. (2020) Electrocoagulation Process in the Context of Disinfection Mechanism. Open Access Library Journal, 7, e6083.

[74] Ghernaout, D., Elboughdiri, N., Ghareba, S. and Salih, A. (2020) Electrochemical Advanced Oxidation Processes (EAOPs) for Disinfecting Water-Fresh Perspectives. Open Access Library Journal, 7, e6257. https://doi.org/10.4236/oalib.1106257

[75] Ghernaout, D., Elboughdiri, N., Ghareba, S. and Salih, A. (2020) Disinfecting Water with the Carbon Fiber-Based Flow-Through Electrode System (FES): Towards Axial Dispersion and Velocity Profile. Open Access Library Journal, 7, e6238. https://doi.org/10.4236/oalib.1106238

[76] Ghernaout, D. and Elboughdiri, N. (2020) Disinfecting Water: Plasma Discharge for Removing Coronaviruses. Open Access Library Journal, 7, e6314. https://doi.org/10.4236/oalib.1106314

[77] Belhout, D., Ghernaout, D., Djezzar-Douakh, S. and Kellil, A. (2010) Electrocoagulation of a Raw Water of Ghrib Dam (Algeria) in Batch Using Iron Electrodes. Desalination and Water Treatment, 16, 1-9. https://doi.org/10.5004/dwt.2010.1081

[78] Ghernaout, D. (2019) Greening Electrocoagulation Process for Disinfecting Water. Applied Engineering, 3, 27-31.

[79] Ghernaout, D. and Elboughdiri, N. (2020) Environmental Engineering for Stopping Viruses Pandemics. Open Access Library Journal, 7, e6299.

[80] Ghernaout, D. (2018) Electrocoagulation Process: Achievements and Green Perspectives. Colloid and Surface Science, 3, 1-5. https://doi.org/10.11648/j.css.20180301.11

[81] Ghernaout, D. and Ghernaout, B. (2012) Sweep Flocculation as a Second Form of Charge Neutralisation-A Review. Desalination and Water Treatment, 44, 15-28. https://doi.org/10.1080/19443994.2012.691699 